\title{
PRAVO NA PRISTUP SUDU EUROPSKE UNIJE
}

Dr. sc. Katarina Knol Radoja, viša asistentica

Pravni fakultet Sveučilišta u Osijeku
UDK: 342.722

Ur.: 12. siječnja 2016.

Pr.: 30. siječnja 2016.

Pregledni znanstveni rad

\section{Sažetak}

Restriktivni pristup tumačenja pretpostavki dopuštenosti podnošenja tužbe za poništenje pred Sudom Europske unije kada su u pitanju fizičke i pravne osobe prije donošenja Lisabonskog ugovora bio je predmetom niza doktrinarnih kritika. Cilj je ovog rada analizirati praktični utjecaj novih pravila o dopuštenosti podnošenja tužbe u svjetlu interpretativnih rješenja koje je dao Sud. Konkretno, analizirat će se imaju li temeljem novog članka 263. stavka 4. Ugovora o funkcioniranju Europske unije privatni podnositelji jednostavniji pristup Sudu Europske unije u usporedbi s onim prije izmjena iz Lisabonskog ugovora. Osim toga, analizirat će se i kompatibilnost navedenog članka s međunarodnim obvezama koje proizlaze iz Aarhuške konvencije o pristupu informacijama, sudjelovanju javnosti u odlučivanju i pristupu pravosuđu u pitanjima okoliša, sporazuma kojeg je i Europska unija stranka.

Na kraju rada, dolazi se do zaključka da, unatoč postojanju određenog napretka u smislu olakšavanja fizičkim i pravnim osobama pristup sudu, tim će osobama izravni pristup, radi osporavanja nezakonitosti akata tijela i institucija Europske unije i dalje biti dostupan samo u ograničenim slučajevima.

Ključne riječi: Sud Europske unije, pristup sudu, dopuštenosti podnošenja tužbe za poništenje.

\section{1. $U V O D$}

Prije izmjena koje je donio Lisabonski ugovor, ${ }^{1}$ tužba za poništenje, osnovni postupak u sustavu sudske kontrole na razini Europske unije (dalje: EU, Unija)

1 Lisabonski ugovor, punim nazivom Ugovor iz Lisabona o izmjenama i dopunama Ugovora o Europskoj uniji i Ugovora o osnivanju Europske zajednice, međunarodni je ugovor potpisan u Lisabonu 13. prosinca 2007. godine. Ugovor predstavlja dopunu Ugovora o Europskoj uniji i Ugovora o osnivanju Europske zajednice. Njime je Ugovor o osnivanju Europske zajednice preimenovan u Ugovor o funkcioniranju Europske unije. Lisabonski ugovor uveo je i Povelju o temeljnim pravima Europske unije. Ugovor je, nakon ratifikacije u svim državama članicama, stupio na snagu 1. prosinca 2009. 
bio je predviđen člankom 230. Ugovora o Europskoj zajednici (dalje: UEZ). ${ }^{2}$ Članak 230. stavak 4. privatnim pojedincima, tj. svim fizičkim i pravnim osobama, dopuštao je izravno osporavanje navodne nezakonitosti akata tijela i institucija Zajednice. U teoriji, ovaj je mehanizam bio osnovni instrument sudske kontrole otvoren za pojedince. No u stvarnosti ta je mogućnost bila iznimno ograničena zbog vrlo strogih pretpostavki dopuštenosti podnošenja tužbe, ali i strogog tumačenja zahtjeva individualnog interesa (individual concern). ${ }^{3}$ Ovakav strogi pristup izazvao je kod praktičara i doktrine niz kritika. ${ }^{4}$

Zbog toga se u sudskoj praksi, ali i doktrini upozoravalo da osim tog izravnog puta osporavanja akata Unije, postoji mogućnost korištenja i neizravnog puta, prvenstveno u vidu postupka prethodnog odlučivanja pred Sudom (dalje: Europski sud, ES). Za taj postupka, jednako kao što primjena normi nacionalnog prava te njihovo tumačenje ovise o zakonskom uređenju i pravnoj tradiciji u pojedinim državama članicama, za tumačenje i odlučivanje o valjanosti primarnog i sekundarnog prava Unije Ugovorom o funkcioniranju Europske unije ${ }^{5}$ (dalje: UFEU), određena je isključiva nadležnost ES-a. Ipak, odluka ES-a u postupku prethodnog odlučivanja upućena je, ne strankama u postupku, nego nacionalnom sudu, pred kojim je taj postupak u tijeku, kako bi na odgovarajući način u konkretnom predmetu primijenilo pravnu normu. Stoga je to jedno od osnovnih sredstava komunikacije i suradnje između ES-a i nacionalnih sudova, ali ne i način ostvarenja prava pojedinaca na pristup tom Sudu.

Ovaj rad procjenjuje doseg novih pravila podnošenja tužbe za poništenje za locus standi privatnih podnositelja zahtjeva. Naime, iako je neupitno da su Lisabonskim ugovorom izmijenjeni uvjeti dopuštenosti podnošenja tužbe za poništenje, utjecaj novog teksta na privatne podnositelje još uvijek je nejasan.

Stoga je cilj ovoga rada analizirati hoće li nova pravila o dopuštenosti podnošenja tužbe, kako ih je u nedavnim presudama tumačio ES, privatnim

2 Općenito o članku 230. UEZ-a, v. Chalmers, D., Monti, G. European Union Law, Cambridge University Press, 2007., str. 416 - 420; Craig, P., De Burca, G. EU Law: Text, Cases and Materials, Oxford University Press, 2008., str. 507 - 517.

3 Albors - Llorens, A., Private parties in European Community Law. Challenging Community Measures, Clarendon Press, 1996., str. 7.

4 Lewis, X., Standing of Private Plaintiffs to Annul Generally Applicable European Community Measures: if the System is Broken, where Should it be Fixed? Fordham International Law Journal, vol. 30., no. 5., 2006/2007., str. 1496 - 1544; Cortés, M., Manuel, J. Ubi ius, Ibi Remedium? - Locus standi of private applicants under Art. 230 (4) EC Treaty at a European Constitutional Crossroad, Maastricht Journal of European and Comparative Law, vol. 11., no. 3., 2004., str. 233 - 261; Parfouru, A. A., Locus Standi of Private Applicants Under the Article 230 EC Action for Annulment : Any Lessons to be Learnt From France? Maastricht Journal of European and Comparative Law, vol. 14., no. 4., 2007., str. 361 - 402; Ward, A., Locus standi under Article 230(4) of the EC Treaty: Crafting a Coherent Test for a Wobbly Polity, Yearbook of European Law, vol. 22., 2003., str. 45 - 77.

5 Ugovor o funkcioniranju Europske unije, 2008, OJ C 115/47. 
podnositeljima olakšati pristup Sudu Europske unije ${ }^{6}$ u usporedbi sa stanjem prije donošenja izmjena.

Osim toga, u radu će se ispitati usklađenost članka 263. stavka 4. UFEU-a, kako ga ES tumači, s obvezama koje proizlaze iz Aarhuške konvencije o pristupu informacijama, sudjelovanju javnosti u odlučivanju i pristupu pravosuđu u pitanjima okoliša $^{7}$ (dalje: Aarhuška konvencija).

Postavši strankom ovog međunarodnog sporazuma 2005. godine, Europska unija je prepoznala da je pristup sudu ključna komponenta zaštite ljudskog prava na zdrav okoliš. Unija je, međutim, uvijek pokazivala nesklonost dopuštanju izravnog osporavanja svojih akata od strane privatnih pojedinaca i nevladinih organizacija pa stoga ne čudi da je primjerenost takvog sustava bio pokušan biti promijenjen u svjetlu članka 9. stavka 3. Aarhuške konvencije. U tim je postupcima, Opći sud, kada se pozvao na dužnost EU-a na postupanje u skladu s međunarodnim obvezama, u konačnici bio nadglasan, ${ }^{8}$ dok je ES izbjegao procjenu jamči li Unija pravo na učinkovitu sudsku zaštitu u pitanjima zaštite okoliša odbijajući priznati izravni učinak članka 9. stavka 3. Aarhuške konvencije. ${ }^{9}$

\section{NAČELO UČINKOVITE SUDSKE ZAŠTITE U PRAVU EUROPSKE UNIJE}

Ubi ius - ibi remedium - tamo gdje je pravo, tamo je i pravno sredstvo. Ovo važno pravno načelo svake pravne države vrijedi i u Europskoj uniji. Jamčeći pravo nekoj osobi, bilo fizičkoj, bilo pravnoj, toj je osobi potrebno osigurati da to pravo može biti učinkovito zaštićeno.

Protivnici restriktivnog tumačenja pretpostavki dopuštenosti podnošenja tužbe za poništenje prije izmjena koje je donio Lisabonski ugovor, tvrdili su da takav pristup krši načelo učinkovite sudske zaštite te može čak dovesti i do uskraćivanja pravde. $^{10}$

6 Sud Europske unije (Court of Justice of the European Union) institucija je Europske unije sa sjedištem u Luxembourgu, a koja obuhvaća: Sud (European Court of Justice) koji se često naziva i Europski sud; Opći sud (General Court), koji se ranije nazivao Sud prvog stupnja te od specijaliziranih sudova - Službenički sud.

7 Hrvatski sabor Konvenciju je ratificirao 8. prosinca 2006. godine, a u Republici Hrvatskoj je stupila na snagu 25. lipnja 2007. (Zakon o potvrđivanju Konvencije objavljen je 12. siječnja 2007. u Narodnim novinama, Međunarodni ugovori, br. 1/07.).

8 Case T-396/09 Stichting Natuur en Milieu and Pesticide Action Network Europe $v$ Commission (CFI, 14 June 2012); Case T-338/08 Vereniging Milieudefensie and Stichting Stop Luchtverontreiniging Utrecht v Commission (CFI, 14 June 2012).

9 Joined cases C-404/12 P and C-405/12 P Council and Others v Stichting Natuur en Milieu and Milieu and Pesticide Action Network Europe (CJEU, 13 January 2015); Joined cases C-401/12 P and C-403/12 P Council and Others v Vereniging Milieudefensie and Stichting Stop Luchtverontreiniging Utrecht (CJEU, 13 January 2015).

10 Albors - Llorens, A., The Standing of private parties to challenge Community Measures: Has the European Court Missed the Boat? Cambridge Law Journal, vol. 62., no. 1., 2003., str. 72 - 92; Usher, J. A., Direct and Individual Concern - An Effective Remedy or a Conventional Solution, European Law Review, vol. 28., no. 4., 2005., str. 575 - 600. 
Načelo učinkovite sudske zaštite, kao i općenito učinkovitost prava Europske unije nalaze se među najznačajnijim pojmovima u sudskoj praksi Europskog suda. Sud ih vidi kao temelj pravnoga sustava Unije i često ih koristi pri obrazlaganju, odnosno kao argument u svojim presudama. Načelo učinkovite sudske zaštite prvi put je artikulirano 1986. godine u predmetu Johnston. ${ }^{11}$ Njime se posredno ili neposredno opravdava, primjerice, načelo prvenstva i izravnog učinka prava Europske unije, obveze nametnute nacionalnim sudovima da zakone tumače u skladu s pravom Unije, izvanugovorna odgovornost država članica ili obveza osiguranja pravnog sredstva za zaštitu prava pojedinaca. ${ }^{12}$

Načelo učinkovite sudske zaštite trebale bi poštovati institucije država članica i Unije. Pri primjeni prava Europske unije u odnosu na pojedince sve institucije to načelo trebaju uzeti u obzir, pri čemu posebnu ulogu imaju nacionalni sudovi i ES. ES je taj koji kontrolira da institucije Unije provode prava pojedinaca, a također i da kontrolira način na koji države članice ispunjavaju obveze koje su im nametnute ugovorima. S druge strane, nacionalni sudovi su uglavnom ti na kojima je da osiguraju učinkovitu sudsku zaštitu prava privatnih pojedinaca jer se oni mogu izravno obraćati ES-u. ${ }^{13}$

Ipak, učinkovita sudska zaštita pretpostavlja dobrovoljnost i dinamičnost u smislu omogućavanja korisniku prava na pokretanje i sudjelovanje u postupku. To, međutim, zahtijeva stalnu pažnju pri tumačenju tekstova kako najbolje služiti identifikaciji ovog načela. Naime, tumačenja nekih odredbi Ugovora, a posebno onih koji se tiču pretpostavki dopuštenosti podnošenja tužbe, često su bila isuviše uska. ${ }^{14}$

Nužnost postizanja učinkovite sudske zaštite proizlazi i iz Europske konvencije za zaštitu ljudskih prava i temeljnih sloboda ${ }^{15}$ (dalje: Europska konvencija, EKLJP) koja se primjenjuje u svim državama članicama Unije. Članak 6. stavak 1. EKLJP-a propisuje da radi utvrđivanja prava i obveza građanske naravi svatko ima pravo da zakonom ustanovljeni neovisni i nepristrani sud pravično, javno i u razumnom roku ispita njegov slučaj. Procesnopravne garancije sadržane u članku 6. stavku 1. tijekom vremena doživjele su različita tumačenja u obimnoj praksi Europskog suda za ljudska prava, pri čemu treba uzeti u obzir da je Sud u svojoj praksi zauzeo posebna shvaćanja o tome što sve može predstavljati građanska

11 Case 222/84, Marguerite Johnston v Chief Constable of the Royal Ulster Constabulary, [1986] ECR 1651, § 20.- 21.

12 Opširniji pregled ranije sudske prakse, v. Tridimas, T., The General Principles of Community Law, 1999., str. 279 - 290.

13 Schermers, H. G., Waelbroeck, D. F., Judicial Protection in the European Union, Kluwer International, Hague, London, New York, 2001., str. 451.

14 Vandersanden, G., La protection juridictionnelle effective: une justice ouverte et rapide?', u: Dony, M., \& Bribosia, E., (eds.), L'avenir du système juridictionnelle de l'Union Européenne, Institut d'Etudes Européennes, Brussels, 2002., str. 119 - 154.

15 Europska konvencija za zaštitu ljudskih prava i temeljnih sloboda, Narodne novine, Međunarodni ugovori, br. 18/97., 6/99., 14/02., 13/03., 9/05., 1/06., 2/10. 
prava i obveze u smislu tog članka. ${ }^{16}$ Iz sudske prakse Europskog suda za ljudska prava proizlazi da članak 6. EKLJP-a ne jamči samo pravo na pristup sudu, on jamči pravo na učinkoviti (effective) pristup sudu. ${ }^{17} \mathrm{U}$ predmetu Golder protiv Ujedinjenog Kraljevstva ${ }^{18}$ Europski sud za ljudska prava zauzeo je stajalište da se članak 6. stavak 1. ne odnosi isključivo na vođenje parnice koja je već počela, već da predmetni članak uključuje i pravo na pokretanje postupaka.

Članak 13. EKLJP-a nadalje propisuje i da svatko čija su prava i slobode povrijeđene ima pravo na djelotvorna pravna sredstva, pa čak i u slučaju kada su povredu počinile osobe koje su djelovale u službenom svojstvu.

Sukladno članku 6. stavku 3. Ugovora o Europskoj uniji ${ }^{19}$ temeljna prava, kako su zajamčena Europskom konvencijom i kako proizlaze iz ustavnih tradicija zajedničkih državama članicama, čine opća načela prava Unije. Budući da temeljna prava čine sastavni dio općih načela, u Uniji treba biti zajamčena i učinkovita kontrola zakonitosti. ${ }^{20}$ Načelo ubi ius ibi remedis predviđeno člankom 47. Povelje o temeljnim pravima Europske unije ${ }^{21}$ također poziva na proširenje uvjeta dopuštenosti. U ovom se članku jamči da svatko čija su prava i slobode, zajamčeni pravom Unije, prekršena, ima pravo na učinkovito pravno sredstvo.

\section{PRAVO NA PRISTUP SUDU EUROPSKE UNIJE PRIJE LISABONSKOG UGOVORA}

Lisabonski ugovor od stupanja na snagu 1. prosinca 2009. godine donosi nova pravila za privatne podnositelje tužbe kojima je namjera osporavati akte koje su donijele institucije i tijela Unije.

U skladu s člankom 263. stavka 4. UFEU-a, koji je zamijenio dotada važeći članak 230. UEZ-a, svaka fizička ili pravna osoba može pokrenuti postupke protiv akta koji je upućen toj osobi ili koji se izravno i osobno odnosi na nju te protiv regulatornog akta koji se izravno odnosi na nju, a ne podrazumijeva provedbene mjere.

16 Opširnije o autonomnom određenju građanskih prava i obveza iz članka 6. Europske konvencije kao i o relevantnoj praksi o pojedinačnim procesnopravnim garancijama koje proizlaze iz tog članka v. Dijk van, P., Hoof van, F. et al., Theory and Practice of the European Convention on Human Rights, 2006., str. 511.

17 Airey v. Ireland, Application no. 6289/73, 9 October 1979.

18 Iako je Sud u ovom predmetu zauzeo stajalište da se ustanovljavanje prava na pristup sudu kao neodvojivog elementa članka 6. stavka 1. ne može smatrati ekstenzivnim tumačenjem Europske konvencije s obzirom na potrebu da se on promatra u svjetlu konteksta i vremena u kojem proizvodi pravne učinke, neki autori ovo shvaćanje Suda u konkretnom predmetu smatraju jednim od najkreativnijih koraka koje je poduzeo u tumačenju navedenog članka. Opširnije v. Harris, O'Boyle \& Warbrick, Law of the European Convention on Human Rights, Oxford, 1995., str. 196.

19 Ugovor o Europskoj uniji 2012/C 326/01.

20 Schermers, Waelbroeck, op. cit. u bilj. 13., str. 450.

21 Povelja o temeljnim pravima Europske unije 2012/C 326/02. 
Sukladno načelu tempus regit actum nova pravila vrijede za sve tužbe podnesene nakon stupanja Lisabonskog ugovora na snagu, bez obzira na datum donošenja osporavanog akta. ${ }^{22} \mathrm{Za}$ zahtjeve podnesene prije 1. prosinca 2009. godine, vrijede pravila o dopuštenosti koja su bila na snazi u vrijeme podnošenja zahtjeva, bez obzira na trenutak kada se odlučivalo o njihovoj dopuštenosti. ${ }^{23}$

Iz članka 263. stavka 4. UFEU-a proizlazi kako je cilj učinjene izmjene bio ublažiti uvjete dopuštenosti podnošenja tužbe za poništenje kako bi se uklonile osnovne prepreke ostvarenja učinkovite sudske zaštite fizičkih i pravnih osoba protiv nezakonitih akata Europske unije.

Prema tekstu članka 230. UEZ-a privatni su podnositelji tužbu za poništenje mogli podnijeti samo protiv njima upućenim odlukama. U slučaju odluke upućene drugoj osobi ili izdane u obliku propisa, odnosno akta opće primjene, pristup pravdi Suda Europske unije bio je dopušten samo ako ih je taj akt izravno i osobno pogađao. Konkretno, pojedinci su trebali dokazati da akt u pitanju ne samo da utječe na njihovu pravnu situaciju (direct concern) ${ }^{24}$ nego i da ih pogađa zbog određenih osobina koje su njima svojstvene ili zbog okolnosti koje ih razlikuju od svih drugih osoba (individual concern), ${ }_{2}^{25}$ što je provjeru dopuštenosti podnošenja tužbe učinilo izuzetno teško ostvarivom. ${ }^{26}$

\subsection{Plaumannov test}

Tumačenje kriterija osobne pogođenosti (individual concern) na način da sporni akt osobu pogađa zbog određenih osobina koje su samo njima svojstvene ili zbog okolnosti koje ih razlikuju od svih drugih osoba usvojeno u predmetu Plaumann, ${ }^{27}$ tzv. Plaumannov test ${ }^{28}$ kritiziralo se iz praktičnih i konceptualnih razloga. ${ }^{29}$

Prvenstveno, ekonomski je nerealan jer tvrtke na tržištu stalno daju ponudu sukladno povećanju potražnje. Stoga su Craig i De Burca iznosili da je argument, da aktivnost uvoza klementina, o čemu je riječ u predmetu Plaumann, može poduzeti bilo koja osoba pa da zbog toga podnositelj nije pojedinačno zainteresiran i da je neuvjerljiv. ${ }^{30}$ Prema tome, podnositelji zahtjeva najvjerojatnije nikada ne bi uspjeli,

22 Case T-18/10, Inuit, 6 September 2011, § 34.

23 Case T-329/08, AJD Tuna, 14 February 2012, § 26 ff.

24 Case C-106 \&107/63, Toepfer v. Commission, 25 June 1964.; također v. i odluku u nedavnom predmetu C-132/12 P, Stichting Woonpunt, 27 February 2014, § 68.

25 Case C-25/62, Plaumann, 15 July 1963, § 107.

26 Eville Brown, L. N., Kennedy, T., The Court of Justice of the European Communities, London, Sweet \& Maxwell, 2000., str. 146.

27 Case C-25/62, Plaumann, 15 July 1963.

28 ...affects them by reason of certain attributes which are peculiar to them or by reason of circumstances in which they are differentiated from all other persons and by virtue of these factors distinguishes them individually... (Case C-25/62, Plaumann, 15 July 1963, § 107.).

29 Craig, De Burca, op. cit. u bilj. 2., str. 489.

30 Ibid. 
osim u vrlo ograničenoj kategoriji retrospektivnih slučajeva, jer se uvijek može tvrditi da su i drugi mogli biti u nekom trenutku pogođeni, odnosno zainteresirani. Štoviše, podnositelju zahtjeva u predmetu Plaumann nije bilo dopušteno podnošenje tužbe jer je pripadao otvorenoj kategoriji podnositelja zahtjeva, pa se stoga smatralo da nije bio pojedinačno zainteresiran. ${ }^{31}$ Ovaj je argument podložan kritici u praktičnom smislu - jer isključuje podnositelje, čak i kada je veoma ograničen broj osoba pogođen. U konceptualnom smislu - ako neku kategoriju smatramo otvorenom samo zato jer bi se teoretski i drugi u nju mogli uključiti, tada svaka odluka s utjecajem u budućnosti neće moći biti osporavana jer će se ta kategorija smatrati otvorenom. ${ }^{32}$

Zbog navedenih se razloga Plaumannov test u doktrini često proglašavao kontraverznim i dok su ga neki percipirali kao pretjerano restriktivnim, ${ }^{33}$ neki su ga ipak smatrali neminovnim. ${ }^{34}$ Neki su autori tvrdili i da ovaj test pretjerano ograničava podnositelja zahtjeva u postizanju pravde i time otvara pitanje ostvarenja učinkovite zaštite temeljnih prava. ${ }^{35}$

Plaumannov test nastavio se primjenjivati u kasnijim slučajevima unatoč svojoj restriktivnosti koju je bilo vrlo teško zadovoljiti. Sud je od podnositelja zahtijevao da pripadaju zatvorenoj kategoriji, čija je pripadnost ustanovljena $\mathrm{i}$ fiksirana na dan donošenja pobijane mjere. ${ }^{36}$ Tako se, primjerice u predmetu Toepfer v. Commission $^{37}$ za podnositelja zahtjeva, uvoznika žitarica, smatralo da je osobno pogođen jer se pobijana odluka odnosi samo na one uvoznike koji su se prijavili za uvozne dozvole na određeni dan. ${ }^{38}$

31 Ibid.

32 Ibid.

33 Birkinshaw, P., A Constitution for the European Union ? - A letter from Home, European Public Law, 2004., vol. 10., no. 1., str. 82.

34 Schwarze, J., The Legal Protection of the Individual against Regulations in European Union Law. European Public Law, 2004., vol. 10., no. 2., str. 297.

35 Birkinshaw, op. cit. u bilj. 33., str. 82.

36 Shaw, J., Law of the European Union, Palgrave Law Masters, 2000., str. 508.

37 Cases 106-107/63 Toepfer v. Commission [1965] ECR 405.

38 Slično i u predmetu Bock v. Commission, Sud smatra da je podnositelj osobno pogođen (A decision is of individual concern to a person when the factual situation created by the decision differentiates him from all other persons and distinguishes him individually just as in the case of the person addressed. A trader is therefore individually concerned by a decision authorizing a Member State to reject the application for an import license made by the said trader prior to the adoption of the decision if the State makes use of that authorization (Case 62/70 [1971] ECR 897.)). Međutim, u predmetu Spijker Kwasten v. Commission zaključuje da nema osobne pogođenosti (A decision addressed to certain Member States with the purpose of authorizing them not to apply community treatment for a fixed period to imports of products originating in a non - member country and in free circulation in the other Member States is not of individual concern to the only importer of the products in question established in the member states to which the decision is addressed since it concerns the importer merely by virtue of his objective status as an importer in the same manner as any other trader who is, or might be in the future, in the same situation (Case 231/82 [1983] ECR 2559). 


\subsection{Razvoj ideje o potrebi za fleksibilnijim pristupom sudu}

Potreba za fleksibilnijim pristupom, posebno kod tumačenja kriterija osobnog interesa bila je izražena u mišljenju Advocate General Jacobsa iznesenom u predmetu UPA. ${ }^{39}$ Jacobs je u tom predmetu istaknuo da načelo učinkovite sudske zaštite zahtijeva da podnositelji zahtjeva imaju pristup sudu koji će ih moći zaštititi od učinaka nezakonitih mjera. Uzimajući u obzir činjenicu da privatnim osobama osporavanje akata koji ne zahtijevaju provedbene mjere može biti teško ili čak nemoguće i činjenicu da postupak pred nacionalnim sudovima, čak i uz provođenje postupka prethodnog odlučivanja ${ }^{40}$ ukazuje na ozbiljne nedostatke u odnosu na ovaj postupak pred ES-om, došao je do zaključka da uspostavljena praksa o locus standi pojedinačnih podnositelja zahtjeva nije u skladu s načelom učinkovite sudske zaštite. $^{41}$

Do sličnih zaključaka došao je i Opći sud u odluci u predmetu Jego-Queré. ${ }^{42}$ Ipak, tu je presudu ES ukinuo ${ }^{43}$ i time potvrdio tradicionalno tumačenje odredbi Ugovora. Ipak, u predmetu UPA poziva države članice na izmjenu članka 230. UEZ-a ako žele proširiti privatnim podnositeljima pristup pravdi. ${ }^{44}$

Pitanjem prava na pristup sudu bavila se i radna skupina u sklopu Konvencije o budućnosti Europe pri čemu su se razmatrale tri opcije reforme postojećeg sustava. ${ }^{45}$ Prva je opcija bila uvođenje novoga pravnog sredstva, izravne tužbe ES-u u slučajevima kada podnositelj zahtjeva tvrdi da su mu povrijeđena temeljna prava. Zatim, druga je opcija bila izmjena članka 230. UEZ-a s naglaskom na problem osobne pogođenosti te je zadnja opcija bila, ostavljanje navedenog članka

39 Case C-50/00P, UPA, Opinion of AG Jacobs, 21 March 2002, § 59-72 i 82-87.

40 Osnovne odredbe o postupku prethodnog odlučivanja sadržane su u čl. 267. UFEU-a. Sukladno tom članku Sud Europske unije nadležan je odlučivati o prethodnim pitanjima koja se tiču: (a) tumačenja Ugovorâ; (b) valjanosti i tumačenja akata institucija, tijela, ureda ili agencija Unije. Ako se takvo pitanje pojavi pred bilo kojim sudom države članice, taj sud može, ako smatra da je odluka o tom pitanju potrebna da bi mogao donijeti presudu, zatražiti od Suda da o tome odluči. Ako se takvo pitanje pojavi u predmetu koji je u tijeku pred sudom neke države članice, protiv čijih odluka prema nacionalnom pravu nema pravnog lijeka, taj je sud dužan uputiti to pitanje Sudu.

41 Case C-50/00P, UPA, Opinion of AG Jacobs, 21 March 2002, § 49.

42 Case T-177/01 Jego-Quéré v. Commission, 3 May 2002, § 41-51.; o tome više v. Hanf, D., 'Facilitating Private Applicants' Access to the European Courts? On the Possible Impact of the CFI's Ruling in Jégo - Quéré', GLJ, vol. 3., no. 7., 2002.

43 Case C-50/00P, UPA, 25 July 2002, § 42-45.; o tome više v. Usher, op. cit. u bilj. 10., str. 575 - 600.; Cortés, Manuel, op. cit. u bilj. 4., str. 233 - 261.

44 While it is, admittedly, possible to envisage a system of judicial review of the legality of Community measures of general application different from that established by the founding Treaty and never amended as to its principles, it is for the Member States, if necessary, in accordance with Article 48 EU, to reform the system currently in force (Case C-50/00P, UPA, 25 July 2002, § 45).

45 European Convention. Modalities and consequences of incorporation into the Treaties of the Charter of Fundamental Rights and accession of the Community/Union to the ECHR. Document CONV 116/02. 
nepromijenjenim. Budući da se prva mogućnost pokazala teško izvedivom, kao i moguće pristupanje Unije Europskoj konvenciji, koja će učinkovito osigurati postojanje sličnog pravnog sredstva, ona nije izabrana. Niti treća opcija, iz očitih razloga, nije izabrana, pa je stoga rasprava bila usredotočena na drugu opciju. ${ }^{46}$

Ostvarivanju navedenoga države članice su se približile potpisivanjem Ustavnog ugovora 29. listopada 2004. godine temeljem kojeg su privatni pojedinci trebali imati olakšani pristup Sudu Europske unije. Ustav Europske unije nije, međutim, nikada stupio na snagu, ali se novi tekst odredbe o locus standi pojedinaca ponovno pojavio u članku 263. stavku 4. UFEU-a izmijenjenog Lisabonskim ugovorom. Novi je tekst, zbog određenih nejasnoća, vrlo brzo privukao pozornost doktrine, ali i samog ES-a, pri čemu su se istaknula dva problema, prvi, značenje pojma regulatornog akta te drugi, značenje izraza akta koji ne podrazumijeva provedbene mjere, a o čemu više infra.

\section{PRISTUP PRIVATNIH PODNOSITELJA SUDU EUROPSKE UNIJE NAKON LISABONSKOG UGOVORA}

U ovom će se dijelu rada, s obzirom na izmjene vezano na uvjete dopuštenosti podnošenja tužbe za poništenje, analizirati je li Lisabonski ugovor poboljšao europski sustav sudske zaštite.

Lisabonski ugovor, kao što je rečeno, odredbom članka 263. stavka 4. UFEU-a modificira uvjete pod kojima fizička ili pravna osoba može pokrenuti postupke protiv akta upućenog toj osobi ili koji se izravno i osobno odnosi na nju te protiv regulatornog akta koji se izravno odnosi na nju, a ne podrazumijeva provedbene mjere. Ispitivanjem ove odredbe jasnim se pokazuje da se temeljna politika koja se odnosi na sustav sudske zaštite nije promijenila. Pojedinici koji žele osporavati akte koji nisu njima upućeni i dalje moraju dokazati da ih se osobno i izravno tiče (individual and direct concern). ${ }^{47}$

Dakle, njihov jedini put za osporavanje akata Europske unije često će i dalje biti samo postupak prethodnog odlučivanja. Ublažena pravila o pravu na pristup sudu primjenjivat će se samo na situacije u kojima su ispunjena dva uvjeta. Prvi je uvjet da je akt koji se osporava regulatoran te drugi, da taj akt ne podrazumijeva provođenje provedbenih mjera.

Prvo pitanje s kojim se ES suočio vezano uz tumačenje novog teksta članka 263. stavka 4. UFEU-a značenje je pojma regulatornog akta, s obzirom na to da Lisabonskim ugovorom isti nije definiran. ${ }^{48}$ Slijedeći Mišljenje Advocate General

46 Blahušiak, I., Access of citizens to the court of justice: the role of regulatory acts, Dny práva - 2010 - Days of Law, 1. ed. Brno: Masaryk University, 2010., str. 7., dostupno na: http:// www.law.muni.cz/content/cs/proceedings/, pristupljeno: 8. siječnja 2015.

47 Lewis, op. cit. u bilj. 4., str. 1532.

48 Koch, C., Locus standi of private applicants under the EU Constitution: preserving gaps in the protection of individuals' rights to an effective remedy, European Law Review, vol. 30. no. 4., 2005., str. 520. 
Kokott ${ }^{49}$ u listopadu 2013. godine ES je potvrdio zaključak Općeg suda u odluci Inuit $^{50}$ gdje se navodi da je regulatorni akt akt opće primjene usvojen u postupku različitom od zakonodavnog postupka definiranog člankom $289 .{ }^{51}$ UFEU-a. ${ }^{52}$ Stoga se može zaključiti da su pojmom regulatorni akt obuhvaćeni svi nezakonodavni akti opće primjene. ${ }^{53}$

Iako niti jedna od tih dviju vrsta akata, regulatornih i (ne)zakonodavnih, nije izričito opisana u članku 288 . UFEU-a ${ }^{54}$ obje vrste imaju određena značenja utemeljena na tekstu Ugovora i prakse ES-a. Članak 288. UFEU-a propisuje da propisi imaju opću primjenu, a sudska praksa nam govori da taj izraz znači da pravni učinci takvih akata nisu usmjereni na neku pojedinačno određenu osobu..$^{55}$ Istodobno, članak 289. UFEU-a izraz zakonski akt definira na način da se odnosi na akte koje su zajedno donijeli Europski parlament i Vijeće ili putem nekog od drugih vrsta postupaka. Ovo je izuzimanje zakonodavnih akata naišlo na otpor doktrine ${ }^{56}$ unatoč nastojanjima Advocate General Kokott da opravda stajalište navođenjem da je ionako manji broj akata zakonodavne naravi. ${ }^{57}$

Vezano uz izraz provedbenih mjera u nekoliko je nedavnih presuda ${ }^{58}$ Općeg

49 Case C-583/11 P, Inuit - AG Kokott Opinion, 17 January 2013, § 30-61.

50 Case T-18/10, Inuit, 6 September 2011, § 56.

51 1. U skladu s redovnim zakonodavnim postupkom, Europski parlament i Vijeće zajedno donose uredbe, direktive ili odluke na prijedlog Komisije. Taj je postupak utvrđen u članku 294.

2. U posebnim slučajevima predviđenima Ugovorima, Europski parlament uz sudjelovanje Vijeća ili Vijeće uz sudjelovanje Europskog parlamenta u skladu s posebnim zakonodavnim postupkom donosi uredbe, direktive ili odluke.

3. Pravni akti doneseni zakonodavnim postupkom su zakonodavni akti.

4. U posebnim slučajevima predviđenima Ugovorima, zakonodavni se akti mogu donositi na inicijativu skupine država članica ili Europskog parlamenta, na preporuku Europske središnje banke ili na zahtjev Suda ili Europske investicijske banke (članak 289. UFEU).

52 Case C-583/11 P, Inuit, 3 October 2013, § 61.

53 O podrijetlu ovog termina v. više u: Griller, S., Ziller, J., The Lisbon Treaty: EU Constitutionalism without a Constitutional Treaty?, Springer-Verlag, 2008., str. 77; Brown, C., Morijn, J., Comment on Jégo-Quéré, Common Market Law Review, vol. 41., no. 6., 2004., str. 1655; Barents, R. The Court of Justice in the draft Constitution, Maastricht Journal of European and Comparative Law, vol. 11., no. 2., 2004., str. 132 - 134.

54 Radi izvršavanja nadležnosti Unije, institucije donose uredbe, direktive, odluke, preporuke i mišljenja. Uredba ima opću primjenu. Obvezujuća je u cijelosti i neposredno se primjenjuje u svim državama članicama. Direktiva je obvezujuća, u pogledu rezultata koji je potrebno postići, za svaku državu članicu kojoj je upućena. Odabir oblika i metoda postizanja tog rezultata prepušten je nacionalnim tijelima. Odluka je u cijelosti obvezujuća. Odluka u kojoj je određeno kome je upućena, obvezujuća je samo za njih. Preporuke i mišljenja nemaju obvezujuću snagu (čl. 288. UFEU).

55 Arnull, A., Private Applicants and the Action for Annulment under Article 173 of the EC Treaty, Common Mkt. L. Rev., vol. 32., 1995., str. 21.

56 Albors-Llorens, A., Remedies Against the EU Institutions After Lisbon: An Era of Opportunity?, Cambridge L. J., vol. 71., 2012., str. 517.

57 Case C-583/11 P, Inuit - AG Kokott Opinion, 17 January 2013, § 50.

58 Case T-279/11, T\&L Sugars, 6 June 2013, § 37; case C-274/12 P, Telefonica, 19 December 2013, § 27; case C-132/12 P, Stichting Woonpunt, 27 February 2014, § 50. 
suda i ES-a prihvaćena njegovo široko tumačenje uključujući svaku mjeru, neovisno o njezinom sadržaju, kojom se na europskoj ili nacionalnoj razini stvara učinak. ${ }^{59}$

S obzirom na regulatorne akte koji ne podrazumijevaju provedbene mjere država članica, odredbom članka 263. stavka 4. UFEU-a ublažene su pretpostavke za podnošenje tužbe pojedinaca. U ovoj situaciji, pojedinac je dužan dokazati samo da ga se akt tiče izravno, a ne i osobno.

Ta se odredba stoga ne odnosi na sljedeće dvije situacije.

Prva, ako pojedinac želi osporiti neregulatoran akt, koji ne zahtijeva provedbene mjere, i dalje mora, kako bi ostvario pristup sudu, dokazati da ga se taj akt izravno i osobno tiče. Ako pojedinac ne bude mogao dokazati da ga se taj akt osobno tiče, tada će u potpunosti ostati bez pravnog sredstva jer tada neće biti na raspolaganju niti nacionalne provedbene mjere koje bi mogao osporavati. Kao rezultat toga, niti neizravni način osporavanja europskog akta kroz postupak prethodnog odlučivanja za pojedinca ne bi bio otvoren. ${ }^{60}$

Druga se situacija odnosi na osporavanje regulatornog ili neregulatornog akta koji zahtijevaju provedbene mjere, kada će pojedinac trebati, kao i u prethodno opisanoj situaciji, dokazati da ga se taj akt izravno i osobno tiče. Ako pojedinac te uvjete ne može ispuniti, i dalje će mu biti otvoren put sudske zaštite u postupku prethodnog odlučivanja. ${ }^{61}$

Ipak, i s obzirom na tu mogućnost treba uzeti u obzir mišljenje Advocate General Jacobsa izneseno u UPA predmetu. ${ }^{62}$ Naime, kako on ističe, u okviru postupka prethodnog odlučivanja pojedinac nema utjecaj na obraćanje nacionalnog suda ES-u, na pitanje radi kojih se mjera nacionalni sud uopće obraća te temeljem kojih osnova. ${ }^{63}$ Nacionalni sudovi (uz izuzetak sudova posljednje instance), najčešće nisu dužni obratiti se ES-u. ${ }^{64}$ Osim toga, kada je pitanje i upućeno sud ga i formulira

59 U doktrini se iznosi kritika takva širokog tumačenja. O tome detaljnije v. Peers, S., Costa, M., Judicial Review of EU Acts after the Treaty of Lisbon, EU Const., vol. 8., 2012., str. 95 - 99; Gormley, L., Access to justice: rays of sunshine on judicial review or morning clouds on the horizon?, Fordham Int'1 L. J., vol. 36., 2013., str.1186-1187.

60 Usher, op. cit. u bilj. 10., str. 599; Dougan, M., The Treaty of Lisbon 2007: Winning Minds, not Hearts, Common Market Law Review, vol. 45., no. 5., 2008., str. 677.

61 Koch, op. cit. u bilj. 48., str. 519.

62 Opinion of Advocate General Jacobs in case C-50/00 Union de Pequenos Agricultores [2002] ECR I-6677, delivered on 21 March 2002.

63 Cf. ibid., § 102.

64 Ako se pojavi pitanje tumačenja osnivačkih ugovora primarnog prava Unije, tumačenja sekundarnog prava, dakle pravnih akata institucija, tijela i agencija Unije ili tumačenja nekog međunarodnog sporazuma kojeg je Unija stranka, kao i drugih akata donesenih na temelju takva međunarodnog sporazuma, osim ako se pitanje odnosi na vanjsku i sigurnosnu politiku, pred bilo kojim sudom države članice, taj sud može, ako smatra da je odluka o tom pitanju potrebna da bi mogao donijeti presudu, zatražiti od ES-a donošenje odluke u postupku prethodnog odlučivanja. Ako se, međutim, takvo pitanje pojavi u predmetu koji je u tijeku pred sudom neke države članice, protiv čijih odluka prema nacionalnom pravu nema pravnog lijeka, u tom slučaju taj sud pitanje mora uputiti ES-u. Dakle, nacionalni sudovi nižih instanci ovlašteni su postavljati takva pitanja, dok su sudovi posljednje instance to dužni učiniti. Više o 
s posljedicom da su zahtjevi pojedinca tada redefinirani ili da se upućeno pitanje odnosi samo na određeni ograničeni raspon mjera osporavanih pred nacionalnim sudom. ${ }^{65}$ Kao rezultat, pojedinac je uvelike ovisan o nacionalnom sudu, pa se postupak prethodnog odlučivanja ne može smatrati njegovim apsolutnim jamstvom učinkovitog pravnog sredstva. ${ }^{66}$

Iz ovoga se može zaključiti da niti izmjene učinjene Lisabonskim ugovorom neće otkloniti nedostatke u sustavu sudske zaštite na razini Unije. Lisabonski ugovor samo s obzirom na regulatorne akte koji ne podrazumijevaju provedbene mjere ublažava pretpostavke za podnošenje tužbe pa će u ovoj situaciji, pojedinac biti dužan dokazati samo da ga se akt tiče izravno, a ne i osobno. Podnositelj, poput Jégo-Quéréa, prema novim režimu stoga ne bi trebao dokazivati osobni interes, budući da osporava regulatoran akt koji ne povlači sa sobom provedbene mjere, nego samo izravni interes. U ostalim kombinacijama, međutim, pojedinac će i dalje morati dokazati da ga se taj akt izravno i osobno tiče.

\section{USKLA円ENOST ODREDBE ČLANKA 263. STAVKA 4. UFEU-a S MEDUNARODNIM OBVEZAMA U SVEZI SA ZAS̆TITOM PRAVA OKOLIS̆A}

Posebne odredbe o pristupu sudskoj kontroli akata institucija Zajednice o zaštiti prava okoliša prije donošenja Aarhuške konvencije, a u svezi s njom i Uredbom 1367/2006 o primjena odredaba Aarhuške konvencije na institucije i tijela Unije $^{67}$ (dalje: Aarhuška uredba) nisu postojale. U vrijeme donošenja Aarhuške konvencije na snazi su bile odredbe članka 230. UEZ-a te je mogućnost takvih pravnih koraka bila njima regulirana. Nakon donošenja te Konvencije, a uskoro i temeljem izmjena koje je donio Lisabonski ugovor pojavila se nada da bi se mogućnosti privatnih podnositelja, a osobito nevladinih organizacija, ostvarivanja prava na pristup ES-u mogle poboljšati.

postupku prethodnog odlučivanja, v. Šago, D., Postupak prethodnog odlučivanja pred Europskim sudom - problemi i moguća rješenja, Zbornik Pravnog fakulteta Sveučilišta u Rijeci, vol. 36., br. 1., 2015., str. 381 - 408.

65 Opinion of Advocate General Jacobs in case C-50/00 Union de Pequenos Agricultores [2002] ECR I-6677, delivered on 21 March 2002., § 42.

66 Koch, op. cit. u bilj. 48., str. 515.; Heffernan, L., Effective Judicial Remedies: The Limits of Direct and Indirect Access to the European Community Courts, The Law and Practice of International Courts and Tribunals, vol. 5., no. 2., 2006., str. 288 - 289.

67 Council Regulation (EC) No 1367/2006 of 6 September 2006 on the application of the provisions of the Aarhus Convention on Access to Information, Public Participation in Decision-making and Access to Justice in Environmental Matters to Community institutions and bodies [2006] OJ L 264/13. 


\subsection{Zaštita prava okoliša prije donošenja Aarhuške konvencije}

Postupak ocjenjivanja akata koje su donijele institucije i tijela Zajednice sukladno članku 230. UEZ-a mogle su pokrenuti dvije skupine podnositelja zahtjeva. Prvu su skupinu činili, tzv. povlašteni podnositelji, a to su države članice, Europski parlament, Vijeće i Komisija koji su tužbu mogli podnijeti bez ograničenja, uz jedini uvjet da zahtjev podnesu u roku od dva mjeseca od objavljivanja osporavanog akta. Ostali podnositelji, fizičke i pravne osobe, činili su drugu skupinu, tzv. nepovlaštenih podnositelja, koji su za podnošenje zahtjeva imali puno više ograničenja. Naime, ti su podnositelji, sukladno članku 230. stavku 4. UEZ-a, o čemu je bilo više govora supra, takav zahtjev mogli podnijeti samo ako ih je akt u pitanju upućen toj osobi ili ako nije njoj upućen, ali se izravno i osobno odnosi na nju.

Kao i u drugim predmetima, i u predmetima zaštite okoliša tumačenje kriterija osobne pogođenosti predstavljalo je glavno ograničenje prava pristupa privatnih podnositelja sudskoj kontroli akata. Predmet Greenpeace v. Commission ${ }^{68}$ vjerojatno je najpoznatiji primjer toga.

U tom je predmetu nevladina organizacija za zaštitu okoliša Greenpeace tražila poništenje odluku Komisije o osiguranju sredstava za izgradnju elektrane na Kanarskim otocima. Podnositelji nevladine organizacije tvrdili su da bi se njihovi posebni interesi o zaštiti okoliša trebali smatrati dovoljnima za zadovoljenje pretpostavki za podnošenje zahtjeva. ES je, međutim, kategorički odbio tu argumentaciju, a nije ni potvrdio da su interesi podnositelja javnoga karaktera (za razliku od privatnih gospodarskih interesa za koje je osmišljen Plaumannov test). Umjesto toga, on naveo je da su javni interesi, kao što je zaštita okoliša, po definiciji difuzni, pa stoga nevladine organizacije ${ }^{69}$ ne mogu ispuniti pretpostavku jedinstvenog položaja prema osporavanom aktu. ${ }^{70}$ Slično kao u ovoj odluci, ES je odlučio u nizu drugih predmeta vezanih uz zaštitu prava okoliša. ${ }^{71}$

68 Case T-585/93 Stichting Greenpeace Council (Greenpeace International) v. Commission [1995] ECR II-2205. Appealed to and upheld by the European Court of Justice; see Stichting Greenpeace Council (Greenpeace International) v. Commission, Case C-321/95, [1998] ECR I-1651.

69 Pravo podnošenja zahtjeva ES nije priznao niti lokalnom stanovništvu zbog neispunjavanja kriterija da se moguće štete u vezi sa zdravstvenim i ekološkim uvjetima samo njih osobno tiču (The applicants are 16 private individuals who rely either on their objective status as "local resident", "fisherman" or "farmer" or on their position as persons concerned by the consequences which the building of two power stations might have on local tourism, on the health of Canary Island residents and on the environment. They do not, therefore, rely on any attribute substantially distinct from those of all the people who live or pursue an activity in the areas concerned and so for them the contested decision, in so far as it grants financial assistance for the construction of two power stations on Gran Canaria and Tenerife, is a measure whose effects are likely to impinge on, objectively, generally and in the abstract, various categories of person and in fact any person residing or staying temporarily in the areas concerned (Case T-585/93 Stichting Greenpeace Council (Greenpeace International) v. Commission [1995] ECR II-2205., § 54.)).

70 Case T-585/93 Stichting Greenpeace Council (Greenpeace International) v. Commission [1995] ECR II-2205., § 51.

71 V. primjerice Case T-236/04 EEB and Stichting Natuur en Milieu v. Commission, [2005]. 


\subsection{Situacija nakon donošenja Aarhuške konvencije}

Europska unija ugovorna je stranka brojnih međunarodnih sporazuma iz kojih proizlaze obveze prema drugim državama i međunarodnim organizacijama. U nastavku će se analizirati kompatibilnost restriktivnog tumačenja ES-a o pretpostavkama dopuštenosti podnošenja tužbe $\mathrm{s}$ obvezama što proizlaze iz Aarhuške konvencije.

Aarhuška konvencija ${ }^{72}$ višestranački je međunarodni sporazum o državnoj odgovornosti i transparentnosti po pitanjima zaštite okoliša usvojen 1998. godine u Aarhusu u Danskoj, a na snagu je stupio 2001. godine. Niz država, među kojima i gotovo sve države članice Europske unije, stranke su tog sporazuma, a u svibnju 2005. godine njegovom je strankom postala i Europska unija. ${ }^{73}$

Aarhuška je konvencija strukturirana u tri stupa, a to su pristup informacijama o okolišu, sudjelovanje javnosti i pravo na pristup pravosuđu u pitanjima okoliša. ${ }^{74}$ Aarhuškom se konvencijom po pitanju okoliša zahtijeva priznanje brojnih procesnih prava za fizičke i pravne osobe, odnosno, najčešće, nevladine organizacije. ${ }^{75}$

Kako bi se preispitalo pridržavanje odredbi ove Konvencije, sukladno članku 15., stranke su dužne uspostaviti fakultativna rješenja, nesuprotstavljene, izvansudske i savjetodavne naravi. U skladu s ovom obvezom, stranke su izabrale odbor (Compliance Committee), koji mogu sazvati i pripadnici javnosti. ${ }^{76}$

S obzirom na svrhu ovoga rada, posebnu pozornost privlači članak 9. Aarhuške konvencije, sukladno kojem je svaka stranka u okviru svojeg domaćeg zakonodavstva dužna osigurati da osoba koja smatra kako su njezina prava zajamčena tom Konvencijom povrijeđena (ako je njezin zahtjev za informacijom zanemaren, nepravilno odbijen, bilo djelomično ili u cijelosti, ako je na njega odgovoreno na neodgovarajući način ili ako se njime nije postupalo sukladno odredbama) ima pristup postupku ocjene pred sudom ili nekim drugim neovisnim i nepristranim zakonski utemeljenim tijelom.

U svezi sa spomenutim člankom, u prigovoru podnesenom 2008. godine Odboru (Compliance Committee) iznosi se kako je Europska unija povrijedila tu svoju obvezu primjenom pretpostavke dopuštenosti podnošenja tužbe u vidu osobnog interesa (individual concern) za privatne podnositelje i nevladine organizacije koji su osporavali odluke institucija Europske unije. ${ }^{77}$ Odbor stoga u

72 Više o Konvenciji v. Rodenhoff, V., The Aarhus Convention and its Implications for the 'Institutions' of the European Community, Review of European Community \& International Environmental Law, vol. 11., 2002., str. 343 - 357.

73 The Aarhus Convention: An implementation Guide (second edition), dostupno na: http:// www.unece.org/env/pp/implementation_guide.html, pristupljeno: 5. studenog 2015.

74 Ibid.

75 Wates, J., The Aarhus Convention: A Driving Force for Environmental Democracy, Journal of European Environmental Planning Law, vol. 2, no. 1., 2005., str. 2 - 11.

76 Compliance Committee, dostupno na: http://www.unece.org/env/pp/ccbackground.html, pristupljeno: 5 . studenog 215.

77 Findings and recommendations of the Compliance Committee with regard to communication ACCC/C/2008/32 concerning compliance by the European Union, dostupno na: http:// 
izvješću donesenom 2011. godine iznosi da su pretpostavke utvrđene člankom 230. UEZ-a, onakve kako ih je ES tumačio, bile isuviše ograničavajuće za fizičke i pravne osobe koje su osporavale akte pred tim sudom. ${ }^{78}$ Osim toga, niti postupak prethodnog odlučivanja, prema mišljenju Odbora, također ne može kompenzirati zahtjeve za pristup pravdi kako je to utvrđeno člankom 9. Aarhuške konvencije. ${ }^{79}$ Odbor je stoga, temeljem navedenih argumenata, zaključio da Europska unija ne postupa u skladu s odredbama iz članka 9. Aarhuške konvencije jer ne osigurava pristup pravdi niti adekvatno i učinkovito pravno sredstvo. ${ }^{80}$

Stupanje Lisabonskog ugovora na snagu i time i izmjena pretpostavki dopuštenosti za podnošenje tužbe za poništenje ipak je u konačnici odvratilo Odbor od donošenja odluke o ne postupanju u skladu s Konvencijom. Ipak, Odbor u izvješću naglašava ukoliko se sudska praksa ES-a nastavi u istom smjeru, Europska unija neće biti u skladu s odredbama iz članka 9. Aarhuške konvencije. ${ }^{81}$ Zbog toga, radi osiguranja usklađenosti s Konvencijom, Odbor potiče drukčije tumačenje pretpostavki dopuštenosti za podnošenje tužbe za poništenje. ${ }^{82}$

Nakon stupanja Lisabonskog ugovora na snagu i dalje ostaje otvorenim pitanje usklađenosti članka 263. stavka 4. UFEU-a sa zahtjevima iz Aarhuške konvencije te posljedica u slučaju da nije. Široka interpretacija provedbenih mjera, ${ }^{83}$ poput one dane u nedavnim predmetima Telefonica ${ }^{84}$ ili Stichting Woonpunt, ${ }^{85}$ vjerojatno će, međutim, potvrditi dvojbe iznesene pred Odborom (Compliance Committee).

Stoga se postavlja pitanje hoće li sudovi Unije biti obvezni tumačiti odredbe Ugovora na način koji će Uniji omogućiti ispoštovati svoje međunarodne obveze.

www.unece.org/fileadmin/DAM/env/pp/compliance/CC-32/ece.mp.pp.c.1.2011.4.add.1_as submitted.pdf, pristupljeno: 10. studenog 2015.

78 Ibid., $\S 86$.

79 Preliminary rulings by the ECJ could not have been "considered as a basis for generally denying members of the public access to the EU Courts to challenge decisions, acts and omissions by EU institutions and bodies" (Findings and recommendations of the Compliance Committee with regard to communication ACCC/C/2008/32 concerning compliance by the European Union, § 81., 90.).

80 Cf. ibid., § 87., 92.

81 Cf. ibid., § 94.

82 Cf. ibid., § 97.

83 Tako ES u predmetu Telefonica ističe da pojam „regulatornih akata koji ne podrazumijevaju provedbene mjere" u smislu zadnje rečenice članka 263. stavka 4. UFEU-a valja tumačiti s obzirom na cilj te odredbe koji teži, kao što to proizlazi iz pozadine njezinog nastanka, a to je da se izbjegne da pojedinac bude prisiljen prekršiti pravo kako bi mogao ostvariti pristup sudu. Kada regulatorni akt proizvodi izravne učinke na pravni položaj fizičke ili pravne osobe, a da ne zahtijeva provedbene mjere, ta bi se osoba mogla naći u situaciji da ostane lišena učinkovite sudske zaštite ako ne bi raspolagala izravnim pravnim sredstvom radi osporavanja zakonitosti tog regulatornog akta pred Sudom Unije. Doista, bez postojanja provedbenih mjera fizička ili pravna osoba, iako se akt u pitanju izravno odnosi na nju, mogla bi ostvariti sudski nadzor tog akta jedino na način da se, nakon što prekrši odredbe navedenog akta, pozove na njihovu nezakonitost u okviru postupaka pred nacionalnim sudovima na čije je pokretanje ovlaštena (Case C-274/12 P, Telefonica, 19 December 2013, § 27.).

84 Case C-274/12 P, Telefonica, 19 December 2013, § 27.

85 Case C-132/12 P, Stichting Woonpunt, 27 February 2014, § 50. 
Sukladno članku 216. stavku 2. UFEU-a sporazumi koje sklapa EU obvezujući su za institucije Unije i za njezine države članice. Iz tumačenja navedene odredbe proizlazi da će i ES, kao institucija Unije, bit obvezan usvojiti tumačenje prava EU-a na način koji će omogućiti njezino ispunjavanje međunarodnih obveza. ${ }^{86}$

Iz prakse ES-a se tako u nekim predmetima može iščitati spremnost na mogućnost tumačenja primarnog prava EU-a u svjetlu međunarodnih obveza, pa je tako primjerice Ugovor tumačen u skladu s ILO Konvencijom. ${ }^{87}$ Određena praksa navodi i na suprotan zaključak pa je tako tumačeno da je primarno pravo Unije, za razliku od sekundarnog, ${ }^{88}$ autonomni pravni sustav koji se ne može narušiti međunarodnim sporazumom. ${ }^{89}$

Radi osiguranja poštovanja odredbi Konvencije, Europski parlament i Vijeće donijeli su Aarhušku uredbu. Aarhuškom se uredbom u članku 10. kreirao interni postupak za preispitivanje upravnih akata. ${ }^{90}$ Problem tumačenja se pojavio zbog toga što se u navedenoj Uredbi upravni akt definira kao svaka pojedinačna mjera u okviru prava zaštite okoliša koju je poduzela institucija ili tijelo Zajednice i koja je pravno obvezujuća i ima vanjske učinke (članak 2. stavak 1. (g) Aarhuške uredbe).

Vezano uz sporno tumačenje prava nevladinih organizacija na pristup sudu po pitanjima okoliša, svojim je odlukama u predmetima Stichting Natuur en Milieu ${ }^{91}$ i Vereniging Milieudefensie ${ }^{92}$ Opći sud poništio odluke Europske komisije u kojima

86 Pallemaerts, M., Access to Environmental Justice at EU Level: has the "Aarhus Regulation" improved the Situation?, u: Allemaerts, M. P., The Aarhus Convention at Ten: Interactions and Tensions between Conventional International Law and EU Environmental Law, Europa Law Publishing, 2011., str. 271 - 312.

87 Case C-43/75, Defrenne, 8 April 1976, § 56/58.

88 Case C-61/94 Commission v. Germany, 10 September $1996 \S 52$.

89 Joined cases C-402 and 415/05 P, Kadi and Al Barakaat v. Council,3 September 2008, § 316.

90 Članak 10. te uredbe glasi: Svaka nevladina organizacija koja ispunjava kriterije iz članka 11. ima pravo podnijeti zahtjev za interno preispitivanje instituciji ili tijelu Zajednice koje je donijelo upravni akt u okviru prava zaštite okoliša odnosno, u slučaju navodnog upravnog propusta, koje je trebalo donijeti takav akt.

Zahtjev se podnosi u pisanom obliku u roku od šest tjedana od donošenja, notifikacije ili objave upravnog akta, ovisno o tome što je najkasnije, odnosno u slučaju navodnog upravnog propusta, $\mathrm{u}$ roku od šest tjedana od dana kada je upravni akt trebao biti donesen. U zahtjevu se navode razlozi za preispitivanje.

Institucija odnosno tijelo Zajednice iz stavka 1. razmatraju svaki zahtjev, osim ako je očito da je zahtjev neosnovan. Institucija odnosno tijelo Zajednice u najkraćem mogućem roku odgovara na zahtjev pisanim obrazloženjem, a najkasnije u roku od 12 tjedana od primitka zahtjeva.

Ako institucije i tijela Zajednice unatoč dužnoj pažnji nisu u mogućnosti postupiti u skladu sa stavkom 2., oni u najkraćem mogućem roku, a najkasnije u roku navedenom u tom stavku, obavješćuju nevladinu organizaciju koja je podnijela zahtjev o razlozima nepostupanja i navode kada to namjeravaju učiniti. Institucija odnosno tijelo Zajednice u svakom slučaju djeluju u roku od 18 tjedana od primitka zahtjeva.

91 Case T-396/09 Stichting Natuur en Milieu and Pesticide Action Network Europe v Commission (CFI, 14 June 2012).

92 Case T-338/08 Vereniging Milieudefensie and Stichting Stop Luchtverontreiniging Utrecht v Commission (CFI, 14 June 2012). 
se na Aarhušku uredbu primijenio restriktivan pristup. Opći sud je prihvatio tužbeni razlog, a koji se temeljio na nezakonitosti odredbe članka 10. stavka 1. Aarhuške uredbe zbog njezine neusklađenosti s člankom 9. stavkom 3. Arhuške konvencije. Sud je te odluke donio pozivajući se na obveze Unije koje proizlaze iz članka 9. stavka 3. Aarhuške konvencije.

U žalbenom je postupku, ${ }^{93}$ međutim, ES takva stajališta odbacio i time izbjegao sagledavanje Aarhuške uredbe u svjetlu međunarodnih obveza Unije. U svojoj je odluci od 13. siječnja 2015. godine stoga ES potvrdio da iz ustaljene sudske prakse tog Suda proizlazi da se u prilog tužbi za poništenje akta sekundarnog prava Unije ili prigovoru utemeljenom na nezakonitosti takvog akta na odredbe međunarodnog sporazuma kojega je Unija stranka može pozvati samo pod dva uvjeta, da to nije protivno naravi i strukturi tog sporazuma te da su te odredbe sadržajno bezuvjetne i dovoljno precizne. ${ }^{94}$ Pozivajući se na odluku u predmetu Lesoochranárske zoskupenie ${ }^{95}$ ES iznosi da članak 9. stavak 3. Aarhuške konvencije ne sadrži nikakvu bezuvjetnu i dovoljno preciznu obvezu koja bi bila takve naravi da izravno uređuje pravni položaj pojedinaca, pa stoga ne ispunjava te uvjete. Budući da su samo pripadnici javnosti koji udovoljavaju mjerilima, ako ih ima, utvrđenima domaćim zakonodavstvom nositelji prava iz toga članka, provedba i učinci te odredbe ovisit će o donošenju naknadnog akta. ${ }^{96}$ Stoga ES zaključuje da je Opći sud, s time što je utvrdio da se pri ocjeni zakonitosti članka 10. stavka 1. Aarhuške uredbe može pozvati na članak 9. stavak 3. Aarhuške konvencije, u svojoj presudi počinio povredu pogrešnog tumačenja prava. ${ }^{97}$

Ovaj bi potvrđeni nedostatak izravnog učinka članka 9. stavka 3. Aarhuške konvencije mogao naići na kritike doktrine pa bi se odluka ES-a mogla označiti kao nazadovanje u zaštiti prava na pristup sudu u pitanjima zaštite okoliša umjesto kretanja unaprijed putem koji je postavila Aarhuška konvencija. ${ }^{98}$

Kao rezultat odluke ES-a, kompatibilnost Aarhuške uredbe s međunarodnim obvezama Unije, najvjerojatnije neće biti predmetom razmatranja pred njezinim institucijama ponovno u skorije vrijeme. To znači da će interni postupak za preispitivanje upravnih akata ostati dostupan samo u kontekstu pojedinačnih akata,

93 Joined cases C-404/12 P and C-405/12 P Council and Others v Stichting Natuur en Milieu and Milieu and Pesticide Action Network Europe (CJEU, 13 January 2015); Joined cases C-401/12 P and C-403/12 P Council and Others v Vereniging Milieudefensie and Stichting Stop Luchtverontreiniging Utrecht (CJEU, 13 January 2015).

94 Joined cases C-404/12 P and C-405/12 P Council and Others v Stichting Natuur en Milieu and Milieu and Pesticide Action Network Europe (CJEU, 13 January 2015), § 46.

95 Case C-240/09 Lesoochranárske zoskupenie VLK v Ministerstvo životného prostredia Slovenskej republiky [2011] ECR I-01255.

96 Joined cases C-404/12 P and C-405/12 P Council and Others v Stichting Natuur en Milieu and Milieu and Pesticide Action Network Europe (CJEU, 13 January 2015), § 47.

97 Cf. ibid., § 53.

98 Roger, A. JC, A Lost Opportunity for Improving Access to Justice in Environmental Matters: The CJEU on the Invocability of the Aarhus Convention (EU Law Analysis, 15 February 2015); dostupno na: http://eulawanalysis.blogspot.hr/2015/02/a-lost-opportunity-forimproving-access.html, pristupljeno: 23. prosinca 2015. 
ostavljajući većinu odluka i mjera u EU-u u području zaštite okoliša izvan opsega Aarhuške uredbe..$^{99}$

\section{ZAKLJUČAK}

Da bi se učinkovita sudska zaštita mogla ostvariti potrebna je dobrovoljnost i dinamičnost pri omogućavanju pokretanja i sudjelovanja u postupku korisniku tog prava. To će zahtijevati stalnu pažnju pri tumačenju tekstova na način koji će najbolje služiti prepoznavanju ovog načela. U svojoj je sudskoj praksi ES, inter alia, potvrdio pravo na pristup sudu, razvoj procesnog prava država članica na način koji osigurava najpotpuniju primjenu prava Unije te čak i stvaranje novih procedura, poput odgovornosti države članice u slučaju povrede tog prava. ${ }^{100}$

Neka su tumačenja ES-a, a posebno onih odredbi vezanih uz pretpostavke dopuštenosti podnošenja tužbe za poništenje akata tijela i institucija Zajednice, bila odveć ograničavajuća. Prije izmjena koje je donio Lisabonski ugovor u doktrini su iznesena stajališta da restriktivno tumačenje pretpostavki dopuštenosti podnošenja tužbe za poništenje krši načelo učinkovite sudske zaštite te time čak dovodi i do uskraćivanja pravde.

Cilj je ovog rada bio stoga istražiti razinu uvažavanja prava fizičkih i pravnih osoba na učinkovitu sudsku zaštitu, odnosno njihova prava na pristup Sudu Europske unije, u svjetlu članka 263. stavka 4. UFEU-a. Sukladno tom članku, svaka fizička ili pravna osoba može pokrenuti postupke protiv akta koji je upućen toj osobi ili koji se izravno i osobno odnosi na nju te protiv regulatornog akta koji se izravno odnosi na nju, a ne podrazumijeva provedbene mjere. Zbog nedefiniranosti pojmova regulatornog akta i provedbenih mjera, uskoro su se javile dvojbe u svezi s njihovim tumačenjem. Nada da će se pritom prihvatiti fleksibilniji pristup, a posebno u svezi $\mathrm{s}$ ispunjavanjem međunarodnih obveza, pokazala se zasada utopijskom.

Tumačenje pojma regulatornog akta, koje proizlazi iz već uspostavljene sudske prakse, ograničava mogućnost podnošenja zahtjeva samo u odnosu na nezakonodavne akte opće primjene. Još veća ograničenja proizlaze iz tumačenja pojma provedbenih mjera, a prema kojem taj pojam uključuje svaku mjeru, neovisno o njezinom sadržaju, kojom se na europskoj ili nacionalnoj razini stvara učinak.

Iz ovoga se može zaključiti da se niti nakon izmjena učinjenih Lisabonskim ugovorom neće otkloniti nedostatci u sustavu učinkovite sudske zaštite i ostvarenju prava na pristup sudu pojedinaca. Naime, pretpostavke za podnošenje tužbe Lisabonski ugovor ublažava samo s obzirom na regulatorne akte koji ne podrazumijevaju provedbene mjere, pa će u ovoj situaciji, pojedinac biti dužan

99 Schoukens, H., Access to Justice in Environmental Cases after the Rulings of the Court of Justice of 13 January 2015: Kafka Revisited?, Utrecht Journal of International and European Law, vol. 31., 2015., str. 62.

100 Cases C-46/93 and C-48/93, Brasserie du Pêcheur and Factortame, [1996] ECR I-1029. 
dokazati samo da ga se akt tiče izravno, a ne i osobno. U ostalim slučajevima pojedinac će i dalje morati dokazati da ga se taj akt izravno, ali i osobno tiče, a što će u skladu s ustaljenom sudskom praksom i dalje biti temeljem, tzv. Plaumannovog testa.

Rezultat je izmjene dakle, da pravna zaštita pojedinca postaje ovisna o obliku akta u pitanju, ${ }^{101}$ a što bi se moglo smatrati u suprotnosti sa sudskom praksom europskih sudova prema kojoj je samo sadržaj akta odlučujući za tumačenje zahtjeva izravnog i osobnog interesa. ${ }^{102}$ U suprotnosti je i s općim načelom učinkovite sudske zaštite iz članka 47. Povelje o temeljnim pravima Europske unije.

Argument da pojedinca potencijalno proglašavanje zahtjeva nedopuštenim ne lišava sudske zaštite, zbog postojanja mogućnosti obraćanja ES-u putem postupka prethodnog odlučivanja, također nije zadovoljavajući. Postupak prethodnog odlučivanja pokreću nacionalni sudovi te ne postoji jamstvo pojedincima da će se nadležni sud u svezi sa spornim pitanjem obratiti ES-u te, ako se i obrati, hoće li postaviti zahtjev onako kako bi ga zainteresirani pojedinac postavio. ${ }^{103}$

Restriktivno tumačenje pokazalo se otegotnim i za ispunjavanje međunarodnih obveza Unije. Tako iz međunarodnog sporazuma, Aarhuške konvencije, kojeg je i Unija stranka, proizlazi da je svaka stranka u okviru svojeg domaćeg zakonodavstva dužna osigurati da svaka osoba koja smatra kako su njezina prava zajamčena tom Konvencijom povrijeđena ima pristup postupku ocjene pred sudom ili nekim drugim neovisnim i nepristranim zakonski utemeljenim tijelom.

Nakon što je izrijekom ukinuo presude Općeg suda, čini se da je ES oduzeo i preostale nade za značajnim unaprjeđenjem položaja nevladinih organizacija za zaštitu okoliša u bližoj i daljoj budućnosti. Naime, iako je Opći sud u svojim odlukama iznio kako smatra da članak 10. stavak 1. Arhuške uredbe nije u skladu s člankom 9. stavkom 3. Arhuške konvencije budući da postupak internog preispitivanja predviđa samo za upravne akte, a koji se člankom 2. stavkom 1. (g) te uredbe definiraju kao svaka pojedinačna mjera, ${ }^{104}$ u konačnici do izravnog djelovanja Aarhuške konvencije ipak nije došlo. U svojoj odluci od 13. siječnja 2015. godine ES iznosi stajalište da Aarhuška konvencija ne ispunjava te uvjete jer ne sadrži nikakvu bezuvjetnu i dovoljno preciznu obvezu koja bi bila takve naravi da izravno uređuje pravni položaj pojedinaca te ukida odluke Općeg suda. Ovim odbijanjem da iskoristi izravno djelovanje Aarhuške konvencije ES je ukinuo i sva očekivanja da će odustati od zastarjelog Plaumannovog pristupa, pa makar samo u slučajevima zaštite okoliša. ${ }^{105}$

101 Koch, op. cit. u bilj. 48., str. 526.

102 Barents, op. cit. u bilj. 53., str. 134.

103 Koch, op. cit. u bilj. 48., str. 515.

104 Case T-396/09 Stichting Natuur en Milieu and Pesticide Action Network Europe v Commission (CFI, 14 June 2012), § 83.

105 Schoukens, op. cit. u bilj. 99., str. 68. 


\section{Summary}

\section{THE RIGHT OF ACCESS TO THE COURT OF JUSTICE OF THE EUROPEAN UNION}

Restrictive approach of the interpretation of assumptions for the approval of filing a claim before Court of Justice of the European Union for annulment when it comes to natural and legal persons before the adoption of the Lisbon Treaty was the subject of a number of doctrinal criticism. The aim of this paper is to analyze the practical impact of the new rules on the admissibility of filing a claim in the light of the interpretative decisions made by the European Court of Justice. Specifically, it will be analyzed whether the private applicants on the basis of the new Article 263, paragraph 4 of the Treaty on the Functioning of the European Union have easier access to Court of Justice of the European Union in comparison with those before the amendments of the Treaty of Lisbon. Moreover, the compatibility of mentioned article with the international obligations arising from the Aarhus Convention on Access to Information, Public Participation in Decision-making and Access to Justice in Environmental Matters the agreement which is the European Union also a party will be analyzed.

At the end of the paper, author reaches the conclusion that in spite of some progress in the sense of relieving the access to the courts to the physical and legal persons, to these individuals direct access to challenge the illegality of acts of the institutions of the European Union will, however, continue to be available only in limited cases.

Keywords: Court of Justice of the European Union, access to court, admissibility of the action for annulment.

\section{Zusammenfassung}

\section{BEITRITTSRECHT ZUM EUROPÄISCHEN GERICHTSHOF}

Restriktiver Deutungsdenkansatz der Bewilligungsannahme der Bestreitungsklageeinreichung vor dem Europäischen Gerichtshof, wenn natürliche oder juristische Personen in Frage sind, war vor der Abschließung des Vertrags von Lissabon Gegenstand einer Reihe doktrinäre Kritiken. Das Ziel dieser Arbeit ist den praktischen Einfluss neuer Regelungen von der Bewilligung der Klageeinreichung im Licht der Interpretationslösungen vom Europäischen Gerichtshof zu analysieren.

Es wird untersucht, ob die Privatkläger laut dem neuem Artikel 263, Absatz 4 des Vertrags über die Arbeitsweise der Europäischen Union einen einfacheren Zugang zu den europäischen Gerichten im Vergleich zu dem vor den Änderungen aus dem Vertrag von Lissabon haben. 
Außerdem wird auch die Kompatibilität des angeführten Artikels mit den internationalen Verpflichtungen, die aus der Aarhus-Konvention über Zugang zu Informationen, der Öffentlichkeitsbeteiligung an Entscheidungsverfahren und dem Zugang zu Gerichten in Umweltangelegenheiten hervorgehen, analysiert, also einer Abmachung deren Mitglied auch die Europäische Union ist.

Am Ende kommt man zur Schlussfolgerung, dass obwohl bestimmte Fortschritte im Sinne des Gerichtzutritts der Natur- und Rechtspersonen erleichtert wurden, diesen Personen wird jedoch ein Direktzugriff wegen der Ungesetzlichkeitsbestreitung der Behördenakten und der Institutionen der Europäischen Union weiterhin nur in begrenzten Fällen ermöglicht.

\section{Schlusswörter: Europäisches Gerichtshof, Gerichtszutritt, Einreichungsbewilligung der Bestreitungsklage.}

\section{Riassunto}

\section{IL DIRITTO D‘ACCESSO ALLA CORTE DI GIUSTIZIA DELL'UNIONE EUROPEA}

L'approccio restrittivo nell'interpretazione dei presupposti di ammissibilità per adire la Corte di giustizia dell'Unione europea per ricorsi di annullamento, quando si tratta di persone fisiche e giuridiche prima dell'entrata in vigore del trattato di Lisbona fu oggetto di numerose critiche della dottrina. Lo scopo di questo lavoro è di analizzare l'influenza pratica di nuove regole circa l'ammissibilità per adire la Corte alla luce di soluzioni interpretative offerte dalla Corte di giustizia dell'Unione europea. In concreto, si analizzerà se i ricorrenti privati abbiano, in forza del nuovo articolo 263, comma 4, del Trattato di funzionamento dell'Unione europea, un accesso più semplice alle corti europee in confronto a quello previsto antecedentemente alle modifiche apportate dal Trattato di Lisbona. Oltre a ciò, si disaminerà la compatibilità del menzionato articolo con gli obblighi internazionali derivanti dalla Convenzione di Aarhus sull'accesso alle informazioni, sulla partecipazione pubblica nel processo decisionale e sull'accesso alla giustizia in materia ambientale; convenzione di cui è parte anche l'Unione europea.

Nella parte finale del contributo si giunge alla conclusione che, nonostante l'esistenza di un certo progresso nel senso della semplificazione nell'accesso alla corte per le persone fisiche e giuridiche, detti soggetti continueranno ad avere un accesso diretto limitato a casi specifici, quando si tratta di contestare l'illegittimità degli atti degli organi e delle istituzioni dell'Unione europea.

Parole chiave: Corte di giustizia dell'Unione europea, accesso alla Corte, ammissibilità della presentazione di ricorso per annullamento. 